\title{
Managing a Circular Food System in Sustainable Urban Farming. Experimental Research at the Turku University Campus (Finland)
}

\author{
Leena Erälinna ${ }^{1}$ and Barbara Szymoniuk ${ }^{2, *}$ \\ 1 Brahea Center, University of Turku, FI-20014 Turku, Finland; leena.eralinna@utu.fi \\ 2 Department of Marketing, Faculty of Management, Lublin University of Technology, 20-618 Lublin, Poland \\ * Correspondence: b.szymoniuk@pollub.pl
}

Citation: Erälinna, L.; Szymoniuk, B. Managing a Circular Food System in Sustainable Urban Farming. Experimental Research at the Turku University Campus (Finland). Sustainability 2021, 13, 6231. https:// doi.org/10.3390/su13116231

Academic Editors: Mario D'Amico and Anna Irene De Luca

Received: 13 March 2021

Accepted: 28 May 2021

Published: 1 June 2021

Publisher's Note: MDPI stays neutral with regard to jurisdictional claims in published maps and institutional affiliations.

Copyright: (c) 2021 by the authors. Licensee MDPI, Basel, Switzerland. This article is an open access article distributed under the terms and conditions of the Creative Commons Attribution (CC BY) license (https:// creativecommons.org/licenses/by/ $4.0 /)$.

\begin{abstract}
People around the world pay increasingly more attention to health, social, environmental, and ethical issues. As a consequence, they seek value in food that is fresh, less processed, and sustainably sourced. The article presents an experimental project supporting the implementation of a circular food system in the city of Turku, Finland. The outcome of the project is a globally replicable concept of managing a local circular food system in sustainable urban farming. The project had two objectives: (1) to reduce food waste in restaurants in the Turku University Campus; (2) to support local recycling of nutrients by composting food waste generated in the pilot restaurant and reuse the nutrients in the process of urban farming. The presented concept is based on the results of two experimental studies. It ties in with UN and EU sustainable development strategies and policies, e.g., Sustainable Development Goals (2, 11, and 12), the European Green Deal, the Farm to Fork Strategy, and the concepts of Circular Economy and Sustainable Cities.
\end{abstract}

Keywords: sustainability; circular economy; sustainable cities; Farm to Fork; circular food system; urban farming; waste hierarchy; food waste; nutrients; food waste recycling; composting

\section{Introduction}

All over the world, environmental awareness is growing among people who want to feel closer to their food, even as they are becoming more urbanized. There is a strong trend to develop urban farming, which offers many health, environmental, and social benefits-provided that its development and management are sustainable. The concepts presented below, of sustainable urban farming and circular food systems, are recommended and supported by global and European policies and programs for sustainable development. The aim of this work is to present the method of managing a circular food system in sustainable urban farming that was created as part of a project carried out at Turku University Campus (Finland), called "Less Waste, More Recycling" ("LeRe"). The overall goals of the project were to reduce the level of food waste in academic restaurants, as well as to promote nutrient recycling and improve the condition of the Archipelago Sea. An additional aim of the project was to encourage academic restaurants to replace the strategy of "doing business-as-usual" with a "less waste and more recycling" approach. The goals were formulated according to the EU "waste hierarchy" concept, set out in Article 4 of the revised Waste Framework (Directive 2008/98/EC) [1]. This concept ranks waste management options according to what is best for the environment. It gives top priority to preventing or reducing waste, and when waste is created-to preparing it for re-use, then recycling, then recovery, and last of all disposal, e.g., at landfills. In the case of food, the following means are recommended: prevention, anaerobic digestion, composting, other energy recovery technologies, and disposal. For the purpose of creating the assumptions for managing the system of promotion of nutrient recycling, finding answers to the following questions was required: (1) Will the Turku University Campus 
community reduce the level of food waste as a result of a creative promotional campaign conducted in academic restaurants, and to what extent? (2) Will it be possible to create a pilot circular food system that will enable the effective use of food waste from university restaurants for the composting process and the use of the produced compost to fertilize the soil in urban farms? The method used in the project was experimental research, and two independent experiments were carried out to achieve both of the above-mentioned goals. The results of the project in the opinion of the authors deserve wide dissemination among people and institutions that are keen on recognizing and using good practices in the field of circular food systems and sustainable urban farming. Thus, the practical purpose of the research is to present the results of the "LeRe" project as a globally replicable concept of educating students (and other people) in the field of reducing food waste as well as of managing a local circular food system in sustainable urban farming.

\subsection{A Broad Context for Circular Food Systems and Sustainable Urban Farming}

The issues of managing circular food systems and practicing urban farming in a sustainable manner ensue from several global development trends as well as policies and strategies of organizations such as the United Nations or the European Union. The first global trend that should be mentioned is the development of bioeconomy. Bioeconomy is a new, interdisciplinary branch of the economy that uses renewable biological resources in a sustainable manner to create goods and services. In such an economy, waste that is inevitable and generated in an efficient system is considered valuable. It is a "byproduct"-a resource that can be recycled or reused. Waste that is generated as a result of poor management is not a desirable resource in the bioeconomic system and should be avoided. The transition to a circular economy brings benefits from an economic, social, and environmental perspective. Regardless of the scale-global, national, regional, or local-it requires careful analysis and preparation for implementation. Otherwise, it can cause economic and social stress [2]. The project presented in this work can help prepare the implementation of circular food systems in urban farming and avoid such stress and fear of failure.

In a circular food system, food waste is processed in order to recover nutrients from it. After being processed, it is added to the soil to enrich it, which enables the production of greater amounts of food. Processing waste, rather than sending it to a landfill or incinerating it, reduces energy and water consumption in food production. The most popular technologies for processing food waste are anaerobic digestion and composting. They stabilize waste and produce residual materials that enrich the soil. This process completes the cycle of a circular food system. It can only be considered safe if the food waste used for processing is free from harmful contaminants, or when these contaminants are destroyed during processing. In the process of managing a circular food system, it is essential to have knowledge about the types of contaminants that appear at different stages of the food supply chain, the sources of these contaminants, and what happens to them during fermentation and composting [3].

Circular food systems and sustainable urban farms fit in with the concept of the so-called sustainable city, or eco-city (also "ecocity"). An eco-city is a city designed with consideration for environmental, social, and economic impact, and a resilient habitat for the existing populations that does not compromise the needs of future generations to thrive in the same environment. It seeks to function without producing more waste than it can assimilate or recycle for new uses or than nature can dilute and absorb harmlessly, and without being toxic to itself or neighboring ecosystems. Its inhabitants' ecological impacts reflect planetary supportive lifestyles. Its social order reflects fundamental principles of fairness, justice, reasonable equity, and also consensus at ample levels of happiness [4]. The United Nations' Sustainable Goal 11 defines sustainable cities as those that are dedicated to achieving green, social, and economic sustainability. The focus also includes minimizing required inputs of energy, water, and food, and drastically reducing waste, output of heat, as well as air and water pollution [5]. According to the 2018 Sustainable Cities Index, 
the top 10 on the list of the most sustainable cities in the world are: London, Stockholm, Edinburgh, Singapore, Vienna, Zurich, Munich, Oslo, Hong Kong, and Frankfurt [6].

The subject of managing a circular food system in sustainable urban farming ties in with EU and UN sustainable development strategies and policies, e.g., the European Green Deal, the Farm to Fork Strategy, Sustainable Development Goals (2, 11, and 12), the concepts of Circular Economy and Sustainable Cities. The European Green Deal sets out how to make Europe the first climate-neutral continent by 2050. It proposes sustainable growth strategy to boost the economy and quality of life, improve people's health and care for nature [7]. A main part of the European Green Deal is the Farm to Fork Strategy, which puts food systems on a sustainable path through following tactics and activities:

- ensuring sustainable food production and food security,

- stimulating sustainable food processing, wholesale, retail, hospitality, and food services practices,

- promoting sustainable food consumption and facilitating the shift to healthy, sustainable diets,

- reducing food loss and waste,

- combating food fraud along the food supply chain [8].

The Farm to Fork (F2F) Strategy may also help to achieve the United Nations' Sustainable Development Goals (SDGs) stated in the Agenda 2030. The F2F Strategy relates to the SDG Goals 2: "End hunger, achieve food security and improved nutrition and promote sustainable agriculture"; $11:$ "Make cities and human settlements inclusive, safe, resilient and sustainable", and 12: "Ensure sustainable consumption and production patterns". According to Target 12.3, the European Commission is committed to halving per capita global food waste at the retail and consumer levels and reduce food losses along production and supply chains, including post-harvest losses, by 2030 [5]. It is worth noting that the "Less Waste, More Recycling" project described in this article provides a solution on how to create a feedback loop based on the Farm to Fork strategy, directing nutrients "from fork to farm".

In this work, the term "urban farming" (urban agriculture, urban cultivation, also urban gardening) is of great importance. They stand for the practice of growing, processing, and distributing food in or around urban areas. Urban farming practiced in a sustainable manner is one of the forms of implementing the so-called civic agriculture. Civic agriculture is a system of agriculture and food production that, unlike the industrial farming system, prioritizes the local socio-economic environment rather than the economic performance of agricultural production [9]. This concept of urban farming was adopted in the implementation of the project described in this study. Urban farming infrastructure can include common areas for community gardens or farms, as well as common areas for farmers' markets in which the food can be sold to the residents of the urban system [10,11]. Urban farming contributes to food security, food safety, improves the quality of the environment, and adds greenery to urban areas. It brings economic, environmental, and social advantages; it improves community food security, has educational functions, links consumers to food production [12], and brings people together [13].

Urban farming interacts with the entire urban ecosystem. Such linkages include: the use of urban residents as key workers, the use of typical urban resources (such as utilizing organic waste as compost or urban wastewater for irrigation), direct links with urban consumers, direct impacts on urban ecology (positive and negative), being part of the urban food system, competing for land with other urban functions, being influenced by urban policies and plans $[10,11]$. Urban agriculture in sustainable cities enables saving energy that would be used in food transportation. There are many types of urban agriculture today, including community and backyard gardens, tactical gardens (e.g., keyhole gardens), street landscaping, forest gardening, greenhouses, planting on rooftops and balconies; green walls, vertical farms, animal husbandry, urban beekeeping, and aquaponics $[11,14,15]$.

The literature on the subject determines six features of urban farming: (1) orientation towards serving the local market, not the mass market; (2) treating agriculture as an integral 
part of community life and not as the production of goods; (3) greater concern about the quality of products than about production efficiency; (4) smaller scope of work and scale of production than in industrial agriculture; (5) relying on knowledge functioning in the social environment and not on standardized practices; and (6) direct relationships with consumers [13] and [16] (p. 85).

Urban farming or allotment gardens have a long tradition in Finland. In the beginning of the 19th century, bigger Finnish cities offered allotments for rent for city-dwellers to satisfy their nutrition and food security needs. In general, Finnish cities have several allotments gardens located on the outskirts with good public transport links. Individual plots in allotment gardens are usually $10 \mathrm{~m}$ x $10 \mathrm{~m}$ in size. Cities are responsible for maintaining public paths in the gardens, sectioning off plots, renting plots to citizens, primary tillage, and access to irrigation water. Allotment gardens, also known as community gardens, are rented to city-dwellers for a period of a year or longer with the purpose of growing vegetables. There are community gardens all over the country in the main cities of Finland-from Helsinki up to Rovaniemi (Lapland) in the north. Allotment gardens are intended for individual gardening, such as growing vegetables. All legal annual plants can be grown in the allotments.

Turku allotment gardens consist of $100-\mathrm{m}^{2}$ plots, which cost around 20 euros per growing season to rent.

Allotment fields are cultivated in the spring, and subsequently divided into allotments and marked with sticks. Two of the fifteen vegetable allotment gardens of Turku are located in the middle of the university campus near the Aura river, which flows through the city to the Baltic Sea and the Archipelago Sea.

\subsection{The Genesis of the Experiment}

The project presented in this work was inspired by the fact that the Finnish Ministry of the Environment published a call for "Proposals for promoting nutrient recycling and improving the condition of the Archipelago Sea". One of the themes was food waste. The research team at the Brahea Center considered how food waste on campus could be reduced in the name of sustainable development, so that it could at the same time affect the condition of the Archipelago Sea. Naturally, various food waste campaigns were first discussed. These methods have been used successfully in the past, but their message often remains on a general and abstract level.

However, the idea was to influence the students more directly. The team considered how the importance of reducing food waste could be demonstrated in practice as a more sustainable use of natural resources. The idea of reusing nutrients from food waste in urban farming arose because Turku and the Turku university campus offer suitable conditions for implementing the project. In an area of a square kilometer in the middle of the campus, there are allotment gardens, student restaurants, and the Aura River, which flows through the Archipelago Sea into the Baltic Sea. The experiment took advantage of an in-campus natural environment with an aim to increase the value of food production, deepen our understanding of the cycle of nature, nutrients, and the importance of preventing food loss as well as nutrient loss. Ultimately, relying on favorable natural resources and on the basis of created concepts, the Brahea Center developed a project with the acronym "LeRe", which received ministerial funding, as well as support from local companies and the academic community of the city of Turku [17].

\section{Materials and Methods}

Project implementers tried to ensure that it was carried out properly and that the results reflected the real world in the best possible way. They decided that the best method which combines scientific research with practice within one project would be the experimental research method. The experimental method is a systematic and scientific approach to research in which the researcher manipulates one or more variables, and controls and measures any change in other variables. It is suitable for research whose goal 
is to examine cause-effect relationships. It may be conducted both in the laboratory and in field settings, in accordance with the aim of the project that is being carried out [18,19]. The described study adopted a broad approach to experimental research, using the socalled quasi-experiment method-i.e., research in which the scientist actively influences something to observe the consequences. This meant that the participants were not randomly assigned, as the project was carried out in settings where randomization was difficult or impossible [18-20].

\subsection{The Research Problem and Aims of Experiments}

The overriding goal of the described project, in line with the requirements set out by the Finnish Ministry of the Environment, was to promote nutrient recycling and improve the condition of the Archipelago Sea. The application problem in the described project was to formulate ways to support a circular food system at the Turku University campus. The University of Turku (UTU), founded in 1920, is the first fully Finnish-speaking university. It is the third largest university in Finland after the universities of Helsinki and Tampere, with 8 faculties and 5 separate departments. Solving the problem required two-pronged action and posing two basic research questions, the answers to which were possible thanks to the experimental research.

The application objectives of the project are presented graphically (Figure 1). The first aim was to reduce food waste at a pilot restaurant by carrying out communication campaigns directed to students. The second aim was to support circular economy and local recycling of nutrients by composting food waste generated in the pilot restaurant and recycling nutrients in urban farming [17].

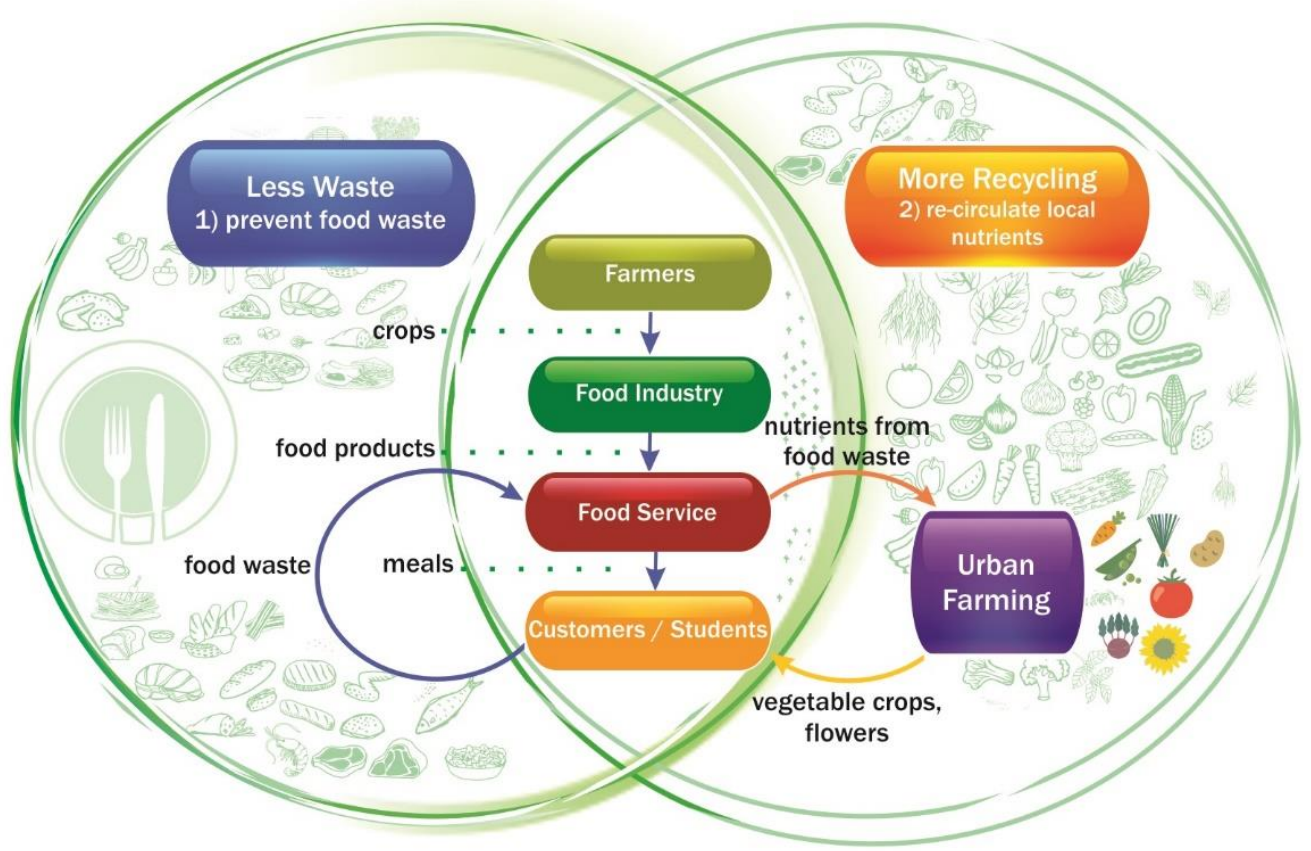

Figure 1. Two application objectives of the "Less Waste, More Recycling" ("LeRe") experimental project. Own creation.

The accomplishment of the application (practical) objectives was conditioned by the achievement of the objectives of the experimental research. Ultimately, it was to result both in the creation of assumptions for managing the promotion of nutrient recycling system as part of the implemented project, and to allow others to replicate both experiments.

The objectives of the experimental research were to formulate answers to two questions: 
1. Will the Turku University Campus community reduce the level of food waste as a result of a creative promotional campaign conducted in academic restaurants, and to what extent?

2. Will it be possible to create a pilot circular food system that will enable the effective use of food waste from university restaurants for the composting process and the use of the produced compost to fertilize the soil in urban farms?

\subsection{Duration, Type of Research, and Sampling Methods}

The project was implemented at the Turku University Campus during a two-year period, from 1 January 2015 to 31 December 2016. Experimental studies and measurements of nutrients were conducted in the same period. In the following years, observations were made of the long-term results of the project.

One-group pretest-posttest research design was chosen to be used in the research part of the project. This research design combines both posttest and pretest study by examining the same group before and after the experiment.

In both experiments, the subjects were selected using the convenience sampling method. A convenience sample is either a collection of subjects that are accessible or a self-selection of individuals willing to participate, e.g., volunteers. This sampling technique is fast, inexpensive, easy, and the subjects are readily available. The convenience sample may differ from an ideal sample that is randomly selected [21]. In the analyzed case, it did not have a significant impact on the results of the research, as the groups subjected to the experiments were representative of the studied population.

\subsection{Conducting Experiment 1: "Less Waste"}

The application objective of the part of the project related to this experiment was to reduce food waste at restaurants in the Turku University Campus. The aim of the experimental research was to find an answer to the question: Will the Turku University Campus community reduce the level of food waste as a result of a creative promotional campaign conducted in academic restaurants, and to what extent?

The Unica company was invited to cooperate in the project. It is a food service company which serves almost 7000 dinners every day in ten restaurants and cafés, mainly on the campuses of the University of Turku and the University of Applied Sciences. Unica has been in operation since 2000; its main owner is Universtas Oy of the Student Union of the University of Turku, and the minority owner Compass Group FS Finland Oy. One of the largest restaurants owned by Unica is Macciavelli. It serves about 1000-1200 meals per day. The main group of Macciavelli's customers includes students from the teacher training college and other students. They are mainly Finnish. International students and teachers constitute between 3 and $5 \%$ of customers.

The first of the four campaign weeks took place at the Macciavelli restaurant. The objective of the campaign was to reduce food waste by one third. The students at the University, who were the main target group of the campaign, were informed about this objective. Customers' plate waste was measured every day during the campaign weeks, and students were informed each day about the amount of waste with signs on the lunch line. In this way, students got a feedback about the previous day's amounts of waste. Students were also provided with an opportunity to give comments on ways in which food waste could be further reduced by participating in a survey and offering direct feedback in face-to-face interviews conducted by the project team. The next three campaign weeks were conducted using the same model in all of the university campus restaurants. Involving both the students and the kitchen staff in the process of reducing food waste was essential. The target population of the research included over 14,000 bachelor and master level students of the Turku University. Most of them were regular customers of Unica's restaurants. During four food waste campaign weeks, the project reached over $50 \%$ of the target group, so this sample may be considered as representative of the population. 
In order to decrease food waste in the Turku University Campus restaurants, it was necessary to increase the awareness of the environmental effects of food waste by conducting an information campaign directed to students, restaurants, and university staff. The main idea of the food waste campaign was as follows: "Mother Nature commands: Leave your plate empty or otherwise your cell phone will suffer. If you take food-don't leave it! By wasting food, we throw away over 600 meals per week." The campaign was implemented in collaboration with the TYY's Environmental Wing, Unica staff, and Dimmi advertising agency (Figure 2).

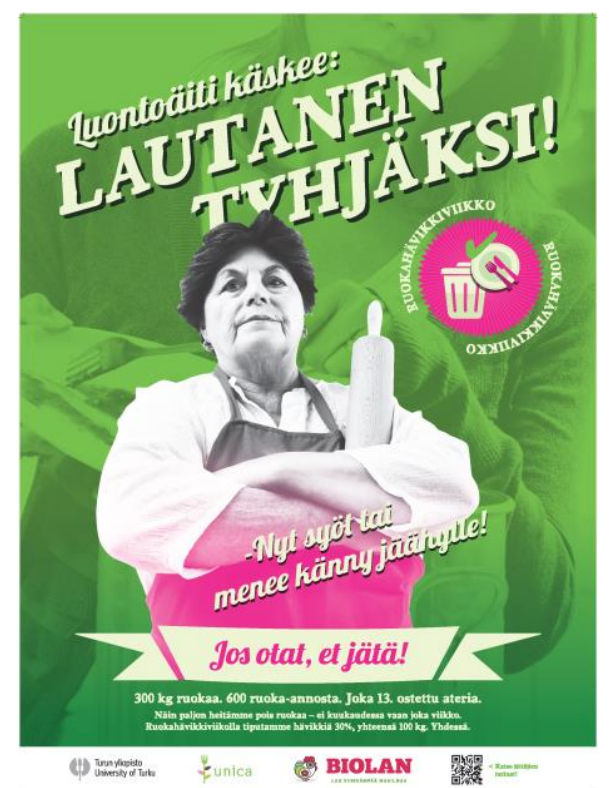

Figure 2. The main message of the "Less waste" campaign weeks: "Mother Nature commands: Leave your plate empty or otherwise your cell phone will suffer. If you take food—don't leave it!".

Different methods of information and involving customers were used during each campaign week, but the main message remained unchanged. Materials on food waste highlighted the connection to the environment and also the condition of the Archipelago Sea, and received extensive positive feedback.

During the campaign weeks, the Macciavelli restaurant used many different ways to promote reducing the amount of food waste. The goal for the whole week was to reduce the amount of food waste from plates by a third. The amount of waste was weighed daily, and customers were informed about it, e.g., with signs on the lunch line as well as on social media channels (Figure 3).

\subsection{Conducting Experiment 2: "More Recycling"}

According to Finnish studies [22] and the experience of the project staff, food waste campaigns generally have short-term effects. For this reason, the "Less Waste" part of the experiment had to be reinforced by the "More Recycling" part. Such a synergy was also useful in increasing an in-depth understanding of and educating the society about the effects of food waste on nature, sea, and nutrient recycling.

The application objective of the part of the project related to this experiment was to support local recycling of nutrients by composting food waste generated in the pilot restaurant and reuse the nutrients in the process of urban farming. The aim of the experimental research was to find an answer to the question: Will it be possible to create a pilot circular food system that will enable the effective use of food waste from university restaurants for the composting process and the use of the produced compost to fertilize the soil in urban farms? Composting plays a significant role in a sustainable circular food system and in urban farming. In Finland, food waste and nutrients recovered from it are not used on a 
large scale as a fertilizer in food and feed production. Food waste is not separated from municipal waste to be collected and processed, so it poses a danger for the environment and a health risk. Composting, as a food waste recycling method, provides a solution to these problems in small scale farming, e.g., urban farming.
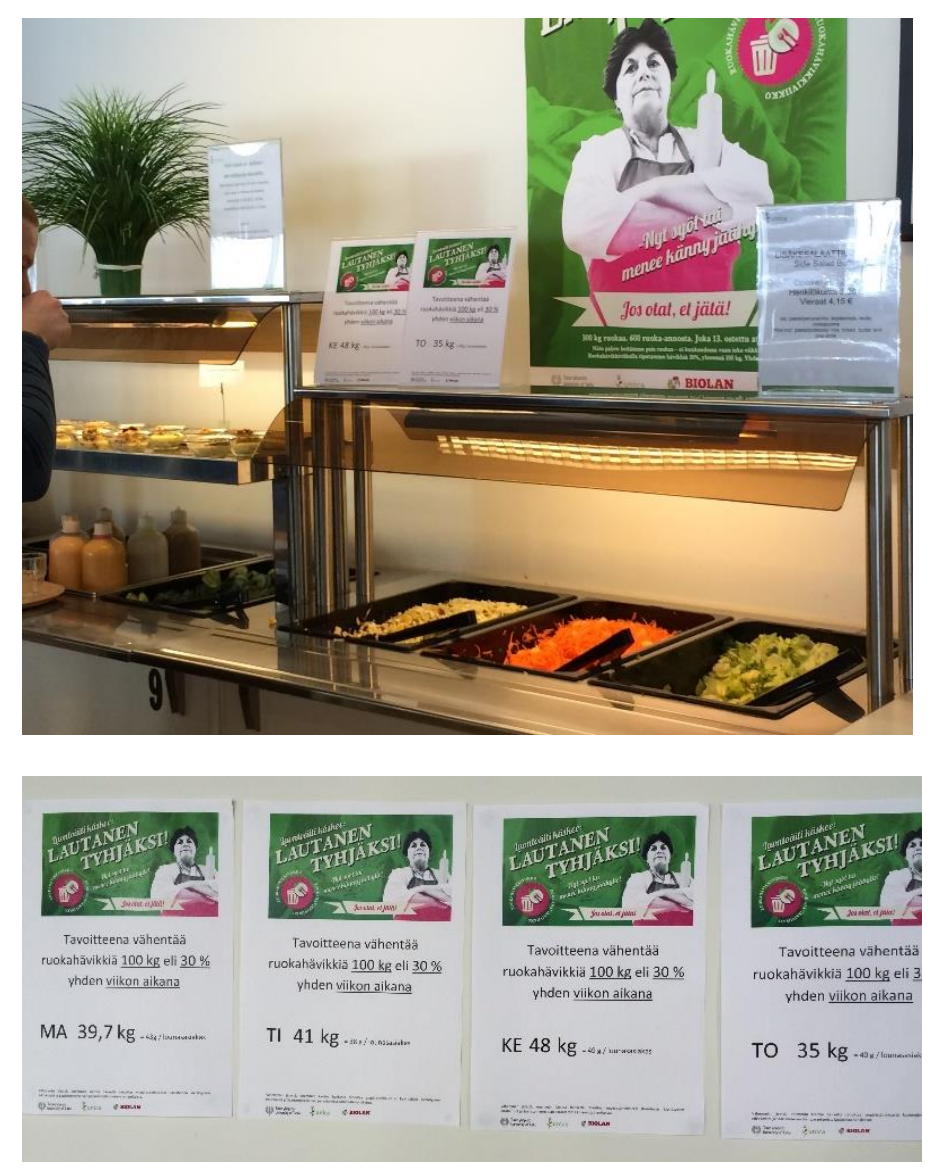

Figure 3. Information signs about the amount of food waste from the last few days for customers on the lunch line of Macciavelli. Photo by Leena Erälinna.

The first practical goal of this part of the experiment was to examine the functionality of a plant composter in a professional kitchen and local nutrient recycling, and to test the model of the "closed nutrient recycling" on the university campus, where nutrients and food circulate locally within the campus, from the campus restaurant to the allotment and back. The second goal was to verify the amount of food wasted, and to reduce that amount by means of the conducted information campaign. The advantage of composting is that the amount of biowaste can be monitored in the specific conditions of the experiment. In order to conduct this experiment, a group of collaborators/volunteers was needed to cultivate the rented plot using self-produced compost. This group was formed by students from the Student Union of the University of Turku (Turun yliopiston ylioppilaskunta, TYY). TYY is a public corporation completely independent of the University of Turku, and one of the oldest student unions in Finland. The role of TYY is to represent its student members, to advance the position of students in society, and to provide them with services ranging from consultations with lawyers to parties as well as hobby and sports opportunities. Under TYY, the Student Union Wings groups operate, i.e., groups of volunteers that implement TYY's values in their activities and function as contact organizations between the students and university staff. Wings are action groups open to all interested students through which they can participate in the activities of the Student Union. One of the four Wings groups of TYY is the Environment Wings. 
The project staff operated together with the Environment Wings. In the beginning of the pilot, the Environment Wings were asked whether there was any interest on their side in participating in nutrients reuse program by composting food waste and using that compost in urban farming. There were 10-15 volunteers who wanted to take part in the project. They formed an urban farming association (Wing Farmers), rented an allotment at the campus, and bought the seeds and seedlings to farm vegetables and flowers for their own use (Figure 4).

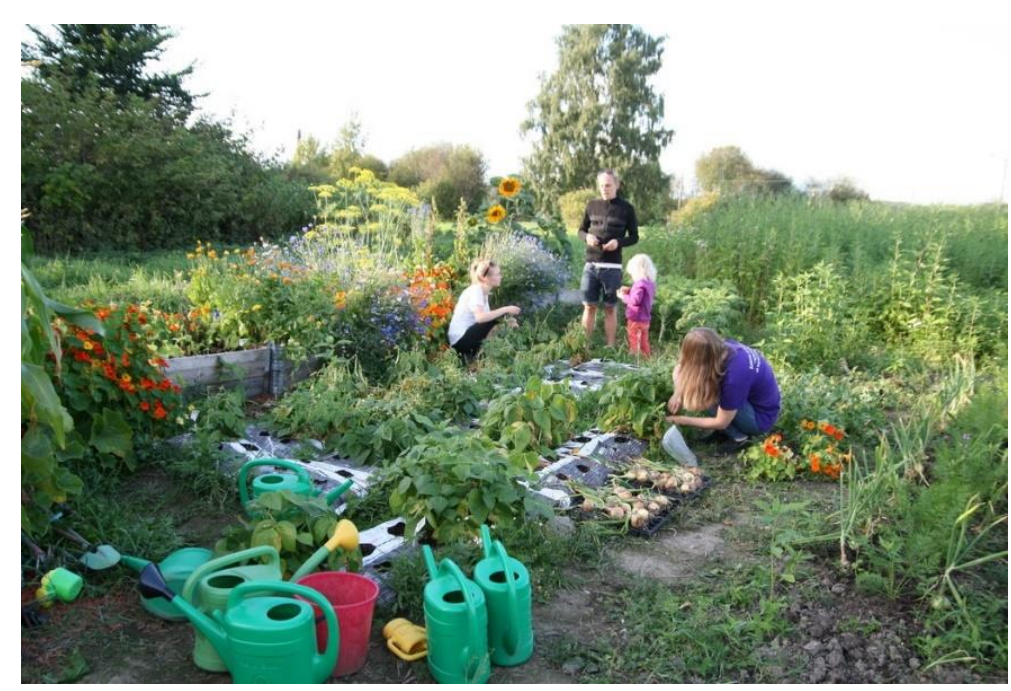

Figure 4. Wing Farmers on the allotment. Photo by Mira Lahtinen.

The Wing Farmers were all university students aged 20-30 years, from many different faculties such as biology, geography, information technology, linguistics, and chemistry. There were slightly more women than men. Farmers changed seasonally as some graduated from university and went to work in other locations or got summer jobs elsewhere. Some of the farmers ( $4-5$ persons) worked continuously throughout the project. They organized their activities independently of the association and continued urban farming even after the experiment had finished. At the beginning of the research, the Wing Farmers did not have any previous experience of growing vegetables or urban farming, so a gardener was hired to help them in practical issues. They became acquainted with co-operative activities but felt that the co-operative registration fee $(400 €)$ was too high. They set up an association whose rules were very similar to the way a co-operative functions; these rules were drawn up with the help of the members who studied law. During the project, the number of members of the association remained fairly stable (from 10 to 15 active members), even if the turnover of members was quite high.

Due to the rainy and cool early spring of the first year, plants grew well, and the harvest was even more than everyone needed. The experiences of the first year of cultivation were positive and encouraging. Urban farming became very popular among students of the co-operative. They developed their urban farming skills, and in the second year, they rented two allotments and farmed independently without the help of the gardener.

The composting process was designed and implemented by the project team in cooperation with the representatives of the Macciavelli restaurant staff, Biolan Ltd., and the students from TYY Wings. The Macciavelli restaurant staff filled the composters and the project team monitored the composting process. Biolan provided the composters and peat/wood chip mix. The farmers from TYY Wings used the nutrient-rich compost on the soil in the rented allotments. In the composting process, three Biolan Quick Composter 550-L were used, and one Biolan Store Composter was utilized for the cooling phase $\left(7.5 \mathrm{~m}^{3}\right)$. Quick Composters have thermal insulation $(5 \mathrm{~cm})$ and they are suitable for year-round composting. They were located at the Macciavelli's waste collection point, and the restaurant staff filled them up once a day with food waste from the kitchen. In this 
experiment only food waste from the kitchen and buffet at the pilot restaurant Macciavelli was used, which was half of the whole food waste at the restaurant. The food waste from the buffet were: salads, pasta, potatoes, and parts of main dishes such as fish, meat, and chicken. The other half was the leftovers from students' plates, which could not be used due to the risk of contamination e.g., with salmonella because it was not certain whether the heating process would successfully eliminate the harmful bacteria.

The personnel of Macciavelli filled the composters and bedded the waste with peat/wood chip mix. A lot of bedding had to be used because food waste was produced in large amounts and it was very wet. Once a week, all the compost was properly mixed or tossed, and checks were performed to see whether the process was in progress and everything was on track, i.e., the temperature during cold periods.

Composting consists of three phases: the warming phase, the hot phase, and the cooling phase. The occurrence of the phases depends on the type of waste being composted and the outside temperature. When the first composter was full, the second one began to be filled (Figure 5).

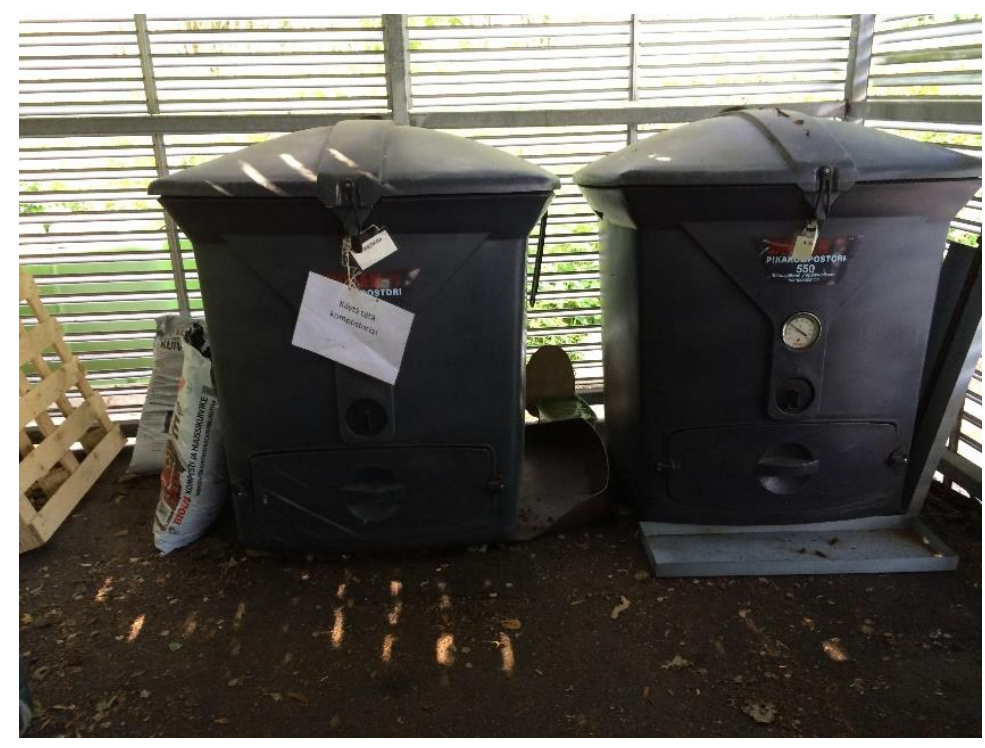

Figure 5. Biolan Quick Composters 550-L in the waste collection points. The note informs the staff which composter is currently being filled. Photo by Leena Erälinna.

When the third composter was filled up, there was room in the first one once again because the compost process had proceeded, and the hot phase was almost finished. The whole cycle took 6-7 weeks depending on the amount and source of waste and the outdoor temperatures. In our experiment, the temperature increased more if protein content was high: even in the winter, the temperature would raise up to 80 degree Celsius. We observed the temperature of composters weekly but did not record those. When compost temperature dropped down and the cooling phase began, we moved the contents of composters to compost storage bins $\left(7.5 \mathrm{~m}^{3}\right)$ together with the Wing Farmers (Figure 6).

The cooling phase took a long time, even as long as several months. This is the phase when the organic matter starts forming the compost. It was stored for after-ripening for a period of six months. Early in the spring, the Wing Farmers moved the cooled down compost to the hired allotment before the cultivation of the soil (Figure 7). The composting process was ongoing throughout the whole period of the experiment. 


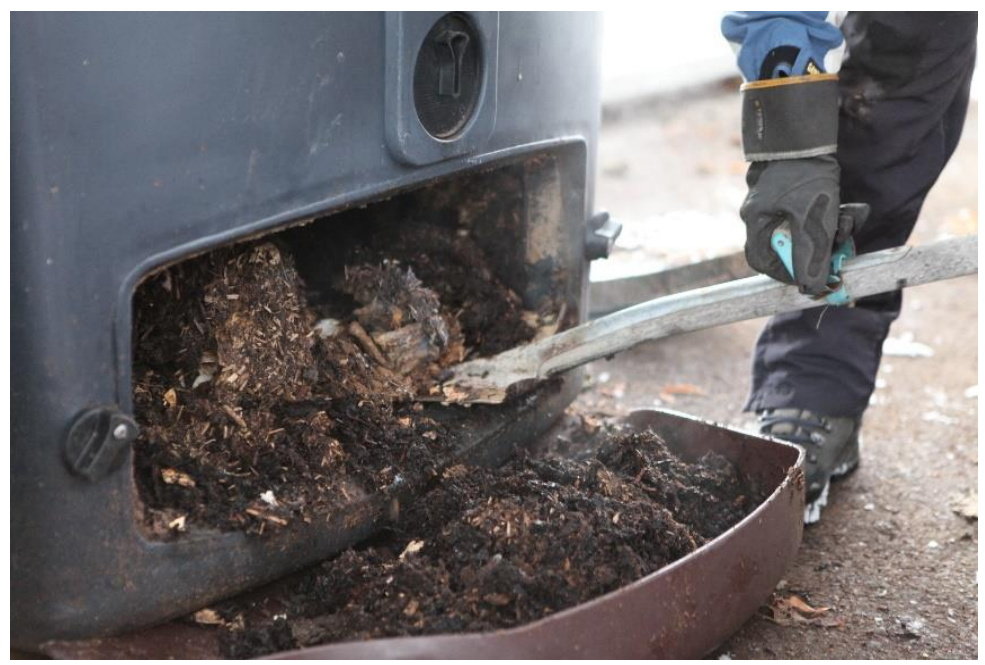

Figure 6. Emptying the composter to move the compost in the cooling phase to storage bins. Photo by Leena Erälinna.

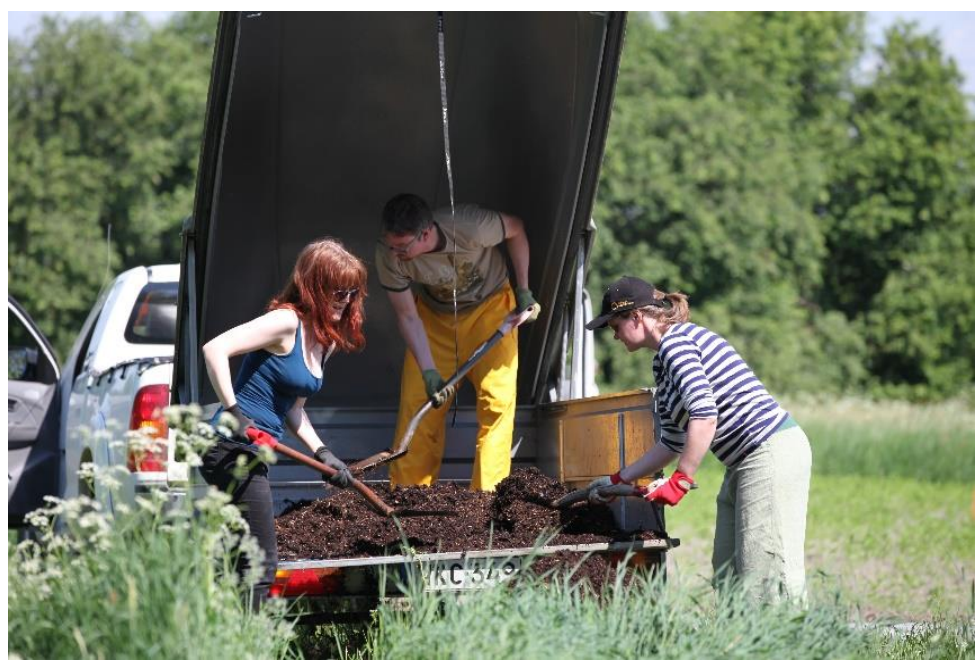

Figure 7. Wing Farmers spread nutritious compost at the allotment before the sowing season. Photo by Leena Erälinna.

\section{Results}

\subsection{Results of Experiment 1: "Less Waste"}

Food waste was measured by the restaurant staff regularly before the campaign weeks in all Unica's restaurants. In the Macciavelli restaurant, plate waste (before the campaign weeks) weighed normally around $300 \mathrm{~kg} /$ week. That means around 25-30 g/day per customer. During the campaign week, the amount of waste was reduced to $200 \mathrm{~kg}$ (i.e., 16-20 g/day per customer). We found out that by information campaigns and interaction with customers we could cut the amount of customer leftovers by 30 percent. However, after the campaign week, the number of leftovers fairly quickly returned to the previous level, which attests to the importance of conducting continuous information campaigns and policy change. The influence of the "Less Waste" campaign on the amount of plate waste is illustrated (Figures 8 and 9). Based on the Mann-Whitney U test, the observed reduction in food waste is statistically significant. 


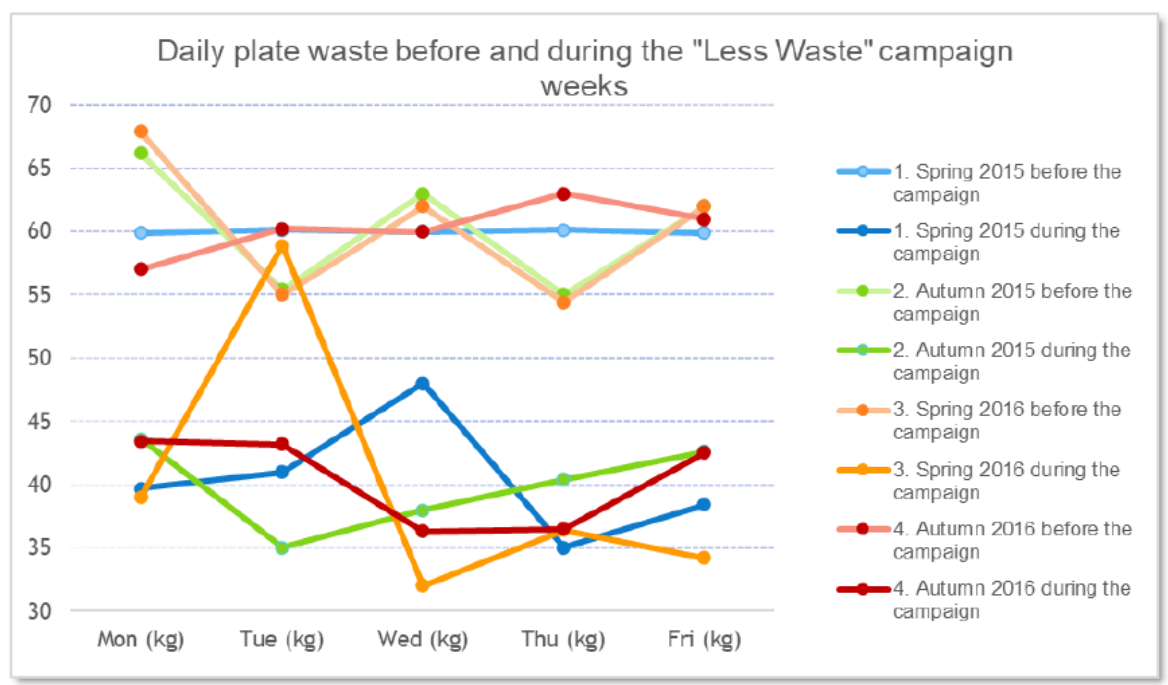

Figure 8. Daily plate waste before and during the "Less Waste" campaign weeks in the pilot restaurant. Own creation.

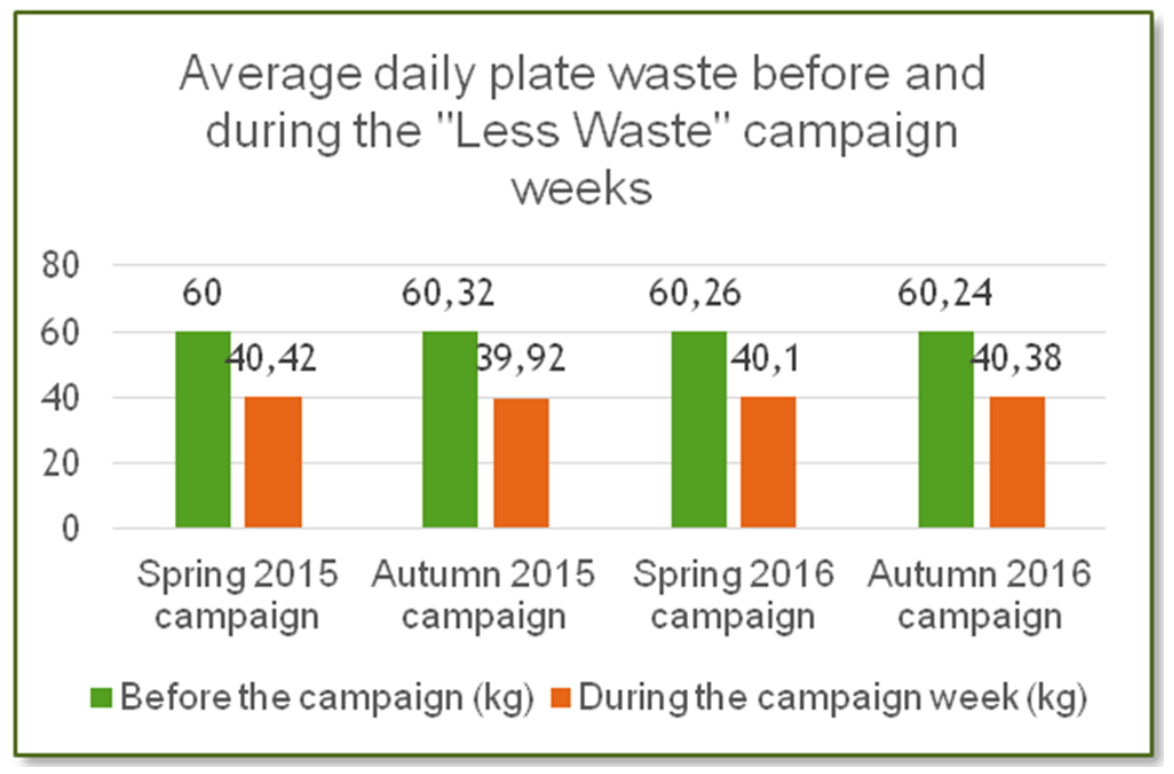

Figure 9. Average daily plate waste before and during the "Less Waste" campaign weeks in the pilot restaurant. Own creation.

The experience from Macciavelli's first campaign week was so positive that the next time all Unica's nine restaurants wanted to take part in the campaign. Campaign materials (table stands, posters, and leaflets) were prominently displayed on restaurant walls, tables, and in the queuing area. As involving restaurants in the process of reducing food waste in all campus restaurants was essential, the project team together with the restaurant staff and students organized a competition among restaurants. The amount of food waste generated in all restaurants, both in the kitchen and on the plates, was weighed during the campaign weeks. These results were compared with previous year's results from Unica's restaurants. The customers of the restaurant that was able to reduce plate waste the most in comparison to the last year were rewarded with dessert coffee and chocolates. The winner, Restaurant Mikro, managed to reduce plate waste by $40 \%$ compared to the waste amount measured in the previous year. In other restaurants, the effectiveness of the campaign was seen in the reduction of the amount of waste by almost a third. Measurements did not differentiate 
between edible and inedible waste, so in some restaurants the weight of inedible waste (i.e., chicken bones) increased the total amount; thus, the target was not quite achieved.

One third of prevented food waste in the pilot restaurant Macciavelli amounted to $110 \mathrm{~kg}$ per week, which means roughly $5500 \mathrm{~kg}$ per year. Samples of the compost were analyzed, and this amount was found to contain about $35 \mathrm{~kg}$ of nitrogen $(\mathrm{N})$ and about $4 \mathrm{~kg}$ of phosphorus (P). Such an amount of nutrients can thus be saved per year in one restaurant by reducing customer food waste.

Reducing food waste in all Turku University Campus student restaurants by a third means saving $550 \mathrm{~kg}$ per week and 27,500 kg per year, with a total nutrient content of 185 $\mathrm{kg}$ of nitrogen and almost $20 \mathrm{~kg}$ of phosphorus. This amount of nutrients could satisfy the nutrient requirement of about two hectares of spring wheat if the phosphorus status of the field was satisfactory by the national and EU environmental standards (Table 1).

Table 1. Yearly nutrient savings achieved by reducing food waste by a third.

\begin{tabular}{ccccc}
\hline & & & Nutrients Recovered from Food Waste \\
\hline & Food Waste kg/week & Food Waste kg/a & N kg/a & P kg/a \\
\hline The pilot restaurant Macciavelli & 110 & 5500 & 35 & 4 \\
Unica's ten restaurants * & 550 & 27,500 & 185 & 20 \\
\hline
\end{tabular}

During the experiment, apart from carrying out an informative and persuasive campaign and taking measurements, observations were also conducted, and opinions of restaurateurs and consumers on effective ways to reduce food waste in restaurants were collected. Restaurants have a variety of ways to reduce food waste, both in the kitchen and in the lunchroom, but achieving lasting results requires daily work, monitoring, and customer involvement. The described project tested various methods of reducing food waste in a student restaurant, and each had its advantages. The views of both professional kitchen staff and consumers on measures to prevent and reuse food waste are summarized below.

Recommendations from professional kitchen staff on how to reduce food waste are:

- regular monitoring of food loss (what, where, why, and how much)

- reducing the size of the plate

- removal of separate salad plates

- $\quad$ limiting the number of dishes

- using whole vegetables and fruits in dishes.

Recommendations from customers on how to prevent food waste in restaurants are as follows:

- leftover lunch on offer

- letting customers take a second helping

- clear labeling of food ingredients displayed in the queuing area

- actively informing customers about the importance of reducing food waste and rewarding them when it is achieved

- waiving food restrictions-they have a reverse effect, e.g., if there is a rule that customers may take no more than 6 meatballs, they will take six instead of taking the amount that would be enough for them

- the opportunity to buy food that is left at the end of the day as a takeaway

- more consideration given to customer feedback

- comfortable dining environment and shorter queuing time

- " "food waste penalty" levied on customers.

The experimental research showed that the academic community of the campus reacted positively to the conducted communication campaign, which was informative and persuasive in nature. The participants' opinions collected during the experiment allow the authors to formulate the conditions for the success of this type of campaign: it should be (1) clearly visible, but not intrusive, (2) creative, so that it arouses interest and 
is remembered, and (3) humorous, so that it is associated with positive emotions. The informative and persuasive message should be changed every season, and the recipients' response to it should be examined on an ongoing basis and corrected if necessary.

\subsection{Results of Experiment 2: "More Recycling"}

In the pilot restaurant, Macciavelli, kitchen waste was composted in three 550-L quick composters for two years. Approximately $7.5 \mathrm{~m}^{3}$ of compost per year was generated from food waste. According to the analysis, the total nitrogen $(\mathrm{N})$ content of the compost was $7.6 \mathrm{~kg} / \mathrm{m}^{3}$, the total phosphorus $(\mathrm{P})$ content was $1.4 \mathrm{~kg} / \mathrm{m}^{3}$, and the total potassium (K) content was $3.0 \mathrm{~kg} / \mathrm{m}^{3}$. This would be sufficient to cover the nitrogen fertilization needs of a hectare of winter carrots, provided that the phosphorus and potassium levels of the soil are good according to the soil sample analysis (N $57 \mathrm{~kg} / \mathrm{ha} ; \mathrm{P} 10.5 \mathrm{~kg} / \mathrm{ha} ; \mathrm{K} 22.5 \mathrm{~kg} / \mathrm{ha}$ ) (Table 2). The produced compost was used in the allotment $\left(100 \mathrm{~m}^{2}\right)$ rented by the students from the farming association (i.e., Wing Farmers). It should be noted that only kitchen and buffet waste from the pilot restaurant was composted. If the whole generated food waste could be composted, it could easily be used instead of chemical fertilizers for cultivating a greater area.

Table 2. Obtaining nutrients by composting food waste from Macciavelli restaurant.

\begin{tabular}{|c|c|c|c|c|}
\hline \multirow{2}{*}{$\begin{array}{c}\text { Food Waste Generated } \\
\mathrm{kg} / \text { week }\end{array}$} & \multirow{2}{*}{$\begin{array}{c}\text { Cooled-Down Compost } \\
\mathrm{m}^{3} / \mathrm{a}\end{array}$} & \multicolumn{3}{|c|}{ Nutrient Analysis of the Compost } \\
\hline & & $\mathrm{N} 7.6 \mathrm{~kg} / \mathrm{m}^{3}$ & $P 1.4 \mathrm{~kg} / \mathrm{m}^{3}$ & $\mathrm{~K} 3.0 \mathrm{~kg} / \mathrm{m}^{3}$ \\
\hline 150 & 7.5 & 57 & 10.5 & 22.5 \\
\hline 300 & 15 & 114 & 21 & 45 \\
\hline
\end{tabular}

It was found out in the experiment that the nutrients obtained from the kitchen waste in one campus restaurant during one year would be sufficient to cover the nitrogen fertilization needs of 1-2 hectares of winter carrots. It was also estimated that by reducing food waste by 30 percent, the ten campus student restaurants could cover nutrient requirement of about two hectares of spring wheat in Finland according to Finnish regulations. The whole process of recycling nutrients was demonstrated by composting food waste and utilizing the nutrient-rich compost in urban farming.

After the project, composting the restaurant's food waste had to be given up. However, Wing Farmers continued their work. After some time, Biolan composters, used in the experiment, designed for consumer use, were replaced by composters that are easy to use in professional kitchens (e.g., Oklin Green Good). They have been successfully utilized in later projects at the University of Turku. Many restaurants and training kitchens in Finland now use such composters.

An important socio-educational result of the project is that urban farming clearly increased the appreciation of food and the sociability of students. An increase in the sense of value of food was clearly reflected, for example, in situations where there was concern about too much harvest or overripe vegetables. It was difficult for the farmers to throw away overripe peas or leave them on the ground. The situation was facilitated by the realization that their nutrients would benefit the following year's harvest. The educational effect of the project was an increase in the students' appreciation of the effort and work needed to grow food, as well as the new knowledge they gained and social competence they developed.

Wing Farmers' activities also strengthened students' community, increasing interaction and leisure activities across faculty boundaries. The farmers enjoyed meeting each-other face-to-face during treatment and watering shifts on the allotment in addition to digital communication. 


\section{Discussion}

The research analyses presented in the previous chapters can be referred to a broader context in terms of: (1) the global need to reduce food waste, (2) the importance of urban farming for sustainable development in the socio-economic aspect, including environmental social education and social well-being.

With reference to point (1) $\mathrm{m}$ about 33\% of food is wasted in the world [23]. This is a very unfavorable phenomenon in the face of the problem of hunger that still plagues humanity. At the level of the European Commission, the body responsible for matters related to food waste is the Directorate-General for Health and Food Safety, which has set a target for 2030-reducing food waste by $50 \%$ in the European Union [24]. The project presented in the article can be an example of good practice in minimizing food waste in mass catering establishments. As a result of the experimental creative communication campaign conducted in one of the academic restaurants, it was possible to achieve an average $30 \%$ reduction in the amount of food waste in the analyzed period. According to the Natural Resources Institute Finland, food service industry in Finland generates about 80 million kilograms of food waste per year [22]. If that amount was reduced by $30 \%$ nationwide across the entire professional kitchen sector, food wastage campaigns would mean 24 million kilos less food waste from the professional kitchen sector alone. We estimated that 24 million $\mathrm{kg}$ of nutrient waste would contain about $160,000 \mathrm{~kg}$ of nitrogen and about $18,000 \mathrm{~kg}$ of phosphorus, which is now thrown away. If the same impact could be achieved globally, the results would be truly revolutionary.

The presented "LeRe" project has shown in an empirical way the importance of nutrients obtained from university restaurants for plant growth. The role of nutrients in the current food system is not evident to the majority of consumers, especially the younger ones, who do not have any connections with agriculture. The appreciation of food proved to play an important role in preventing food waste and loss. In Finland, not only chemical fertilizers are imported, but also a lot of nutrients in the food that is later thrown away. Most of these nutrients are wasted and eventually end up polluting waterways and the environment.

With reference to point (2) The "More Recycling" part of the project confirmed the principles formulated in the literature on the subject that resource efficiency in sustainable agri-food systems can be increased by:

- minimal amount of external inputs;

- closing nutrient loops;

- minimizing the pollution of the environment with waste and emissions of harmful substances;

- valorizing agri-food wastes.

A careful analysis of the entire agri-food system enables productivity to be increased at all stages of the value chain: from primary production using precision farming techniques, distribution, and communication with consumers, to the use of agri-food waste in the bioeconomy [16]. The most organic, sustainable way of using agri-food waste and building soil for any garden is composting. Through composting, most kitchens can reuse 30 percent or more of their waste [21].

In recent years, the so-called community composting, with which the system described in this article has a lot in common, is becoming increasingly popular in cities. Unlike in-home compost systems, it allows for sending a composting expert round to each of the sites to monitor the health of the compost and to ensure the composters remain ratfree. A decentralized community composting model is easier to roll out at scale than a commercial system, which requires trucks to transport the compost as well as infrastructure to process it. A decentralized system (for example, with composters conveniently located near catering establishments and urban farming plots) means more co-benefits for the community, such as building local soil, carbon storage, and increased resilience through more local food growing [25]. 
The experiment carried out as part of the project showed that the participating students considered urban farming to be a good way to become acquainted with food production and nutrient cycling. The excellent harvest and the success of cultivation increased their motivation for farming. In addition to economic benefits, farming also brought social benefits. Young farmers appreciated being a part of a community and considered social contacts as positive aspects of urban agriculture. Gardening and watering shifts were anticipated as opportunities to spend time with others face-to-face. In this way, students from different disciplines got to know each other, thus increasing social cohesion and commitment to the place of study. Moreover, the project has shown that urban farming is a way of increasing the sense of value of food, which is one key part of reducing food waste-both through growing one's own fruit and vegetables, and reducing leftovers. Determining how much work, time, nutrients, and energy it takes to grow food, how it is that "home-grown potatoes taste so different", contributes to increasing respect for food. Taking care of vegetables and fruits made work a concrete experience for the young farmers participating in the project and substantially increased their appreciation of food.

These feelings of the students participating in the project confirm the fact that the level of urban agriculture reflects the level of economic and social development of the city. Urban agriculture can have a large impact on the social and emotional well-being of the residents. Urban farms and gardens are often places that facilitate positive social interactions, which also contribute to overall social and emotional well-being. Moreover, they help to improve social networks within the communities in which they are located [11]. This type of urban agriculture is associated with the concept of the so-called social farming. It is an activity that uses agriculture and agricultural resources for social and professional integration, various types of social therapy, providing services for children, supporting the activity of seniors, and for other tasks of great importance for local communities. As shown by research on the role and impact of social agriculture on environmental changes carried out in Italy, good social farming practices are often associated with the circular economy model. They spread within a specific economic system and contribute to its success [26]. In the described project it was exactly like that: the practice of social farming was linked to the circular food system model.

Another important argument for the development of sustainable urban agriculture is the scientifically proven fact that being in a friendly social environment, increased physical activity, exposure to sunlight, and a healthy diet increase the level of serotonin in the human brain. Serotonin improves well-being and increases the sense of happiness, thus counteracting cardiovascular and mental diseases, including depression [27].

Summing up the issues related to the socio-cultural meaning of sustainable urban faming, it should be emphasized that Finland, where the described experiments were carried out, has been the world leader in social and economic well-being for several years. It can therefore be a good example to follow for other countries wishing to improve their citizens' happiness [28]. In the World Happiness Report 2020, Finland was announced the world's happiest country for the third time. On a cultural level, Finnish contentment stems from a sense of community, trust, and social cohesion among citizens [29,30]. Finland is also famous for ecologization of consumer behavior, i.e., a process of revision in consumers' consciousness and attitudes which takes place in the sphere of the whole social and market activity of the consumers, and not only in their buying decisions. Such "eco-consumers" tend to make many "small steps for nature" every day, contributing to the sustainable development of their local environment [31,32].

As far as the replication of this model is considered, many limitations should be taken into consideration. Firstly, campaigns such as the "Less Waste" campaign are not enough to reduce food waste permanently because more behavioral factors and long-term educational work are needed to achieve more lasting results. Secondly, this particular experimental project was implemented in a specific society: at the Turku University Campus, mainly among university students. The model may reveal new dimensions and yield other effects with different target groups, different cultural contexts, and different social awareness 
of the principles of sustainable development. Thirdly, if the project is to be replicated elsewhere, various factors related to legislation, regulations and infrastructure must be taken into consideration.

The presented considerations on the effects of the described project in a broad economic and social context, as well as on the conclusions of the conducted experiments, indicate future research directions. They should be aimed at translating the presented concepts into wider economic practice. The goals of further research may include: (1) creating universal economic and financial models of circular food systems (taking into consideration both in-house cooking and mass catering) in sustainable farming (both urban and rural), and (2) identification of social determinants of the effectiveness of these models.

\section{Conclusions}

The results of experiments presented in the work and the ensuing concepts (Less Waste and More Recycling) concerning managing a local circular food system in sustainable urban farming can be replicated all over the world. They can be treated as the so-called pilot studies, and then adapted to specific conditions of further research or implementation.

The concept of "Less Waste" promoting the reduction of food waste in restaurants is fully replicable. It can be implemented wherever consumers have an impact on the quantity and quality of food consumed: both at home and in mass catering establishments. It is especially suitable for kindergartens and schools of all levels, as it should be part of the general environmental education aimed at reducing all waste. The experiment carried out as part of the described project showed that by means of a creative, noticeable, informative, and persuasive communication campaign conducted in a university restaurant, it is possible to influence the behavior of the community and obtain a significant reduction in the amount of leftovers on their plates. It also showed that with the passage of time and with customer rotation, the results of communication campaigns decrease within a few weeks and the situation returns to the state from before the campaign. This means that information and persuasion campaigns encouraging pro-environmental behavior should be constantly, but not intrusively, repeated. It is important that the messages are visible, aesthetic, and that they are characterized by creativity with elements of humor.

The concept of "More Recycling" concerning the local circular food system in sustainable urban farming is also replicable, provided that the necessary adaptations to specific conditions are made. Particular attention should be paid to the conclusion of the experiment that, apart from the ecological and economic benefits resulting from the recovery of nutrients from food waste in academic restaurants and their use in urban farming, there are significant social benefits of the analyzed concept. They result from successful cooperation in a group, established relationships, and spending time actively in nature. Such activities help to improve everyday lives, well-being, and the sense of happiness of the involved farmers.

To sum up, in managing sustainable development solutions that are to be effectively implemented in business practice, one thing is certain: these solutions must be both pro-environmental and pro-social, as well as financially profitable for all parties involved.

Author Contributions: Conceptualization, L.E. and B.S.; methodology, L.E. and B.S.; formal analysis, L.E. and B.S.; investigation, L.E. and B.S.; writing-original draft preparation, L.E. and B.S.; writingreview and editing, B.S.; visualization, L.E. and B.S.; project administration, L.E.; funding acquisition, L.E. The authors have read and agreed to the published version of the manuscript. All authors have read and agreed to the published version of the manuscript.

Funding: The project was funded by the Ministry of the Environment (Finland) through the program "Proposals for promoting nutrient recycling and improving the condition of the Archipelago Sea" as well as by Unica Ltd., Biolan Ltd., and the Keskitien Tukisäätiö Foundation. This research received no external funding.

Institutional Review Board Statement: Not applicable.

Informed Consent Statement: Not applicable. 


\section{Data Availability Statement: Not applicable.}

Acknowledgments: The project was implemented in close cooperation with Unica Ltd., Biolan Ltd., TYY's environmental wing and Brahea Centre (UTU). In addition, the Wing Farmers Association was established during the project.

Conflicts of Interest: The authors declare no conflict of interest.

\section{References}

1. Guidance on Apzplying the Waste Hierarchy. Available online: https://www.gov.uk/government/publications/guidance-onapplying-the-waste-hierarchy (accessed on 15 April 2021).

2. Ward, S. The 'circular economy' applied to the agri-food sector. In Proceedings of the European Commission DG Research \& Innovation Hosted Conference on: 'Harnessing Research and Innovation for FOOD: A Science Policy Dialogue', Brussels, Belgium, 16 October 2017; Volume 2030. Available online: https:/ / ec.europa.eu/info/sites/info/files / conferences/food2030_20 17/3.6.3_sustainable_techno-economic_solutions_agrocycle-shane_ward_0.pdf (accessed on 4 February 2021).

3. Thakali, A.; MacRae, J.D. A review of chemical and microbial contamination in food: What are the threats to a circular food system? Environ. Res. 2021, 194, 110635. [CrossRef] [PubMed]

4. What Is an Ecocity? Available online: https:/ / ecocitystandards.org/ecocity/ (accessed on 21 February 2021).

5. Transforming Our World: The 2030 Agenda for Sustainable Development. Resolution Adopted by the General Assembly on 25 September 2015, United Nations, A/RES/70/1. Available online: https://sustainabledevelopment.un.org/content/ documents / 21252030\%20Agenda\%20for\%20Sustainable\%20Development\%20web.pdf (accessed on 5 February 2021).

6. The World's Most Sustainable Cities. Available online: https://www.worldatlas.com/articles/the-world-s-most-sustainablecities.html (accessed on 6 February 2021).

7. The European Green Deal. Communication from the Commission, Brussels, COM(2019) 640 Final. Available online: https://eurlex.europa.eu/legal-content/EN/TXT/?qid=1576150542719\&uri=COM\%3A2019\%3A640\%3AFIN (accessed on 4 February 2021)

8. A Farm to Fork Strategy for a Fair, Healthy and Environmentally-Friendly Food System. In Proceedings of the Communication from the Commission to the European Parliament, the Council, the European Economic End Social Committee and the Committee of the Regions, $\operatorname{COM}(2020) 381$ Final, Brussels, Belgium. Available online: https:/ / eur-lex.europa.eu/legal-content/EN/TXT/ ?uri=CELEX:52020DC0381 (accessed on 30 May 2021).

9. Lyson, T.A. Civic agriculture and community problem solving. Cult. Agric. 2005, 27, 92-98. [CrossRef]

10. Sustainable City. Available online: https://en.wikipedia.org/wiki/Sustainable_city (accessed on 4 February 2021).

11. Urban Agriculture. Available online: https://en.wikipedia.org/wiki/Urban_agriculture (accessed on 6 February 2021).

12. Specht, K.; Siebert, R.; Hartmann, I.; Freisinger, U.B.; Sawicka, M.; Werner, A.; Thomaier, S.; Henckel, D.; Walk, H.; Dierich, A. Urban agriculture of the future: An overview of sustainability aspects of food production in and on buildings. Agric. Hum. Values 2014, 31, 33-51. [CrossRef]

13. Poulsen, M.N.; Neff, R.A.; Winch, P.J. The multifunctionality of urban farming: Perceived benefits for neighbourhood improvement. Local Environ. 2017, 22, 1411-1427. [CrossRef]

14. An Introduction to Urban Farming, Types, Ideas, and Benefits. Available online: https://agriculturegoods.com/urban-farming/ (accessed on 6 February 2021).

15. 11 Types of Urban Agriculture. Available online: https://simplicable.com/new/urban-agriculture (accessed on 6 February 2021).

16. Lyson, T.A. Civic Agriculture: Reconnecting Farm, Food, and Community; Tufts University Press: Lebanon, NH, USA, 2004.

17. Erälinna, L. Less food waste, more recycling-Nutrients reuse at the Turku University Campus. Brahea Centre, University of Turku. In Proceedings of the Poster presentation at the 4th Global Food Security Conference, Le Corum, Montpellier, France, 7-9 December 2020.

18. Experimental Research Designs: Types, Examples \& Methods. Available online: https://www.formpl.us/blog/experimentalresearch (accessed on 18 February 2021).

19. Ross, S.M.; Morrison, G.R. Experimental Research Methods. Available online: https://www.researchgate.net/publication/2013 82131_Experimental_Research_Methods (accessed on 19 February 2021).

20. Blakstad, O. Experimental Research. Available online: https:/ / explorable.com/experimental-research (accessed on 19 February 2021).

21. Convenience Sampling. Available online: https:/ / explorable.com/convenience-sampling (accessed on 19 February 2021).

22. Silvennoinen, K.; Koivupuro, H.K.; Katajajuuri, J.M.; Jalkanen, L.; Reinikainen, A. Ruokahävikki Suomalaisessa Ruokaketjussa: Foodspill 2010-2012-Hankkeen Loppuraportti; MTT: Luke, MD, USA, 2012.

23. Zuckerman, A. 48 Food Waste Statistics 2020/2021: Causes, Impact \& Solutions. Available online: https://comparecamp.com/ food-waste-statistics / (accessed on 20 February 2021).

24. Directorate-General Heath and Food Safety. Available online: https://ec.europa.eu/info/departments/health-and-food-safety_ en (accessed on 20 February 2021).

25. Building Soil. Not Landfills. 2020 IS Going to Be a Big Year for Community Composting in Wellington. Available online: https:/ / sustaintrust.org.nz/blog/community-compost-wellington (accessed on 2 February 2021).

26. Nicolosi, A.; Laganà, V.R.; Di Gregorio, D.; Privitera, D. Social Farming in the Virtuous System of the Circular Economy. An Exploratory Research. Sustainability 2021, 13, 989. [CrossRef] 
27. Young, S.N. How to increase serotonin in the human brain without drugs. J. Psychiatry Neurosci. 2007, 32, 394-399. Available online: http://jpn.ca/wp-content/uploads/2014/04/32-6-394.pdf (accessed on 20 February 2021). [PubMed]

28. Väänänen, H. What Makes Finland The Happiest Country In The World? Forbes. 26 May 2020. Available online: https://www. forbes.com/sites/heikkivaananen/2020/05/26/what-makes-finland-the-happiest-country-in-the-world/?sh=1749d6c175cc (accessed on 20 February 2021).

29. World Happiness Report 2020. Available online: https:/ /worldhappiness.report/ed/2020/\#read (accessed on 20 February 2021).

30. It's a Three-Peat, Finland Keeps Top Spot as Happiest Country in World. Available online: https://worldhappiness.report/ news /its-a-three-peat-finland-keeps-top-spot-as-happiest-country-in-world/ (accessed on 20 February 2021).

31. Skowron, S.; Szymoniuk, B. Marketing and sustainable development. Probl. Sustain. Dev. 2014, 9, 39-46. Available online: https:/ / papers.ssrn.com/sol3/papers.cfm?abstract_id=2478611 (accessed on 22 February 2021).

32. Jak Promować Proekologiczny Styl Życia i Gospodarowania: Przykłady Dobrych Praktyk z Islandii, Finlandii i Niemiec (How to Promote Proecological Lifestyle and Management: Examples of Good Practices from Iceland, Finland and Germany). Available online: https:/ / www.researchgate.net/publication/338775937_Jak_promowac_proekologiczny_styl_zycia_i_gospodarowania_ Przyklady_dobrych_praktyk_z_Islandii_Finlandii_i_Niemiec (accessed on 22 February 2021). 